\title{
Serum Insulin-Like Growth Factor Binding Protein 7 as a Potential Biomarker in the Diagnosis and Prognosis of Esophagogastric Junction Adenocarcinoma
}

\author{
Can-Tong Liu ${ }^{1,2}$, Yi-Wei Xü ${ }^{1,2,3}$, Hong Guo ${ }^{4}$, Chao-Qun Hong ${ }^{5}$, Xin-Yi Huang ${ }^{2}$, Yu-Hao Luo ${ }^{1}$, Shi-Han Yang ${ }^{6}$, Ling-Yu Chu ${ }^{2}$, En- \\ Min $\mathrm{Li}^{2,3,7}$, and Yu-Hui Peng ${ }^{1,2,3}$ \\ ${ }^{1}$ Department of Clinical Laboratory Medicine, the Cancer Hospital of Shantou University Medical College, ${ }^{2}$ Precision Medicine Research \\ Center and ${ }^{3}$ Guangdong Esophageal Cancer Research Institute, Shantou University Medical College, Departments of ${ }^{4}$ Radiation Oncology and \\ ${ }^{5}$ Oncological Laboratory Research, the Cancer Hospital of Shantou University Medical College, ${ }^{6}$ Department of Dermatology and Venereology, \\ Shantou Central Hospital, and ${ }^{7}$ Department of Biochemistry and Molecular Biology, Shantou University Medical College, Shantou, China
}

Background/Aims: Esophagogastric junction adenocarcinoma (EJA) is a malignant tumor associated with high morbidity and has attracted increasing attention due to a rising incidence and low survival rate. Pathological biopsy is the gold standard for diagnosis, but noninvasive and effective tests are lacking, resulting in diagnoses at advanced stages. This study explored the diagnostic value of insulin-like growth factor binding protein 7 (IGFBP7) in EJA. Methods: A total of 120 EJA patients and 88 normal controls were recruited, and their serum levels of IGFBP7 were measured by enzymelinked immunosorbent assay. Receiver operating characteristic (ROC) curve analysis was used to assess the diagnostic value, and Pearson chi-square analysis was used to evaluate the correlation between IGFBP7 and clinical parameters. Kaplan-Meier survival analysis was carried out to assess the effect of IGFBP7 on overall survival (OS). Results: The levels of IGFBP7 were higher in both early- and late-stage EJA patients than in normal controls $(p<0.001)$. The area under the ROC curve for EJA patients was 0.794 (95\% confidence interval [Cl], 0.733 to 0.854$)$, with a cutoff value of $2.716 \mathrm{ng} / \mathrm{mL}$, a sensitivity of $63.3 \%$ (95\% Cl, $54.0 \%$ to $71.8 \%)$ and a specificity of $90.9 \%$ (95\% Cl, $82.4 \%$ to $95.7 \%)$. For the diagnosis of early-stage EJA, the same cutoff value and specificity were obtained, but the sensitivity of IGFBP7 was 54.3\% (95\% Cl,
$36.9 \%$ to $70.8 \%)$. Patients with low IGFBP7 protein expression had lower OS than those with high expression ( $p=0.034)$. The multivariate analysis showed that IGFBP7 is an independent prognostic factor for EJA ( $p=0.011)$. Conclusions: Serum IGFBP7 acts as a potential diagnostic and prognostic marker for EJA. (Gut Liver 2020;14:727-734)

Key Words: Insulin-like growth factor binding protein-7; Esophagogastric junction; Adenocarcinoma; Diagnosis; Prognosis

\section{INTRODUCTION}

In recent decades, the incidence of esophagogastric junction adenocarcinoma (EJA) has rapidly increased in both western countries and eastern Asia. ${ }^{1}$ EJA is usually divided into three different types according to the 1998 Siewert classification. ${ }^{2}$ Tumors with centers from $5 \mathrm{~cm}$ to $1 \mathrm{~cm}$ above the esophagogastric junction are defined as Siewert type I, while tumors with the centers located $1 \mathrm{~cm}$ above to $2 \mathrm{~cm}$ below the junction are type II, and tumors with centers located $2 \mathrm{~cm}$ to $5 \mathrm{~cm}$ below the junction are type III. However, in accordance to the 8th edition of the American Joint Committee on Cancer Cancer Staging Manual, ${ }^{3}$ esophagogastric junction cancers with centers no more

\footnotetext{
Correspondence to: Yu-Hui Peng ${ }^{\mathrm{a}}$, En-Min $\mathrm{Li}^{\mathrm{b}}$, and Yi-Wei $\mathrm{Xu}^{\mathrm{c}}$

${ }^{a}$ Department of Clinical Laboratory Medicine, the Cancer Hospital of Shantou University Medical College, No.7 Raoping Road, Shantou 515041, China

Tel: +86-137-1591-2739, Fax: +86-754-8856-0352, E-mail: pengyuhui666@163.com

${ }^{\mathrm{b}}$ Department of Biochemistry and Molecular Biology, Shantou University Medical College, No.22 Xinling Road, Shantou 515041, China

Tel: +86-138-0929-1605, Fax: +86-754-8890-0847, E-mail: nmli@stu.edu.cn

cDepartment of Clinical Laboratory Medicine, the Cancer Hospital of Shantou University Medical College, No.7 Raoping Road, Shantou 515041, China

Tel: +86-159-8970-1200, Fax: +86-754-8856-0352, E-mail: yiwei512@126.com

Received on April 21, 2019. Revised on September 18, 2019. Accepted on October 30, 2019. Published online December $13,2019$.

pISSN 1976-2283 eISSN 2005-1212 https://doi.org/10.5009/gnl19135

Can-Tong Liu and Yi-Wei Xu contributed equally to this work as first authors.

(a) This is an Open Access article distributed under the terms of the Creative Commons Attribution Non-Commercial License (http://creativecommons.org/licenses/by-nc/4.0) which permits unrestricted non-commercial use, distribution, and reproduction in any medium, provided the original work is properly cited.
} 
than $2 \mathrm{~cm}$ from the inferior esophageal sphincter are staged as esophageal adenocarcinoma (Siewert type I or II), while those more than $2 \mathrm{~cm}$ are staged as stomach cancers (Siewert type III). ${ }^{3}$ Overall survival (OS) for EJA is poor, with a 5-year survival of less than 25\% in China. ${ }^{4,5}$ In clinical practice, the diagnosis of EJA is mostly dependent on pathological biopsy after endoscopy or surgery, both of which are invasive methods. A valuable and noninvasive method is urgently needed for early diagnosis.

The insulin-like growth factor (IGF) family is composed of IGFs, IGF receptors and IGF-binding proteins (IGFBPs), ${ }^{6-8}$ which play a vital role in regulating cell proliferation, differentiation, and apoptosis. ${ }^{9}$ Among them, IGFBP7 binds IGF-I and IGF-II with low affinity. ${ }^{10}$ However, IGFBP7 has been found to be related to several diseases, such as acute kidney injury ${ }^{11}$ and chronic obstructive pulmonary disease. ${ }^{12}$ Similarly, both high and low expression of IGFBP7 has been observed in various cancer tissues, such as gastric ${ }^{13}$ and colorectal cancer. ${ }^{14}$ In gastroesophageal cancer, IGFBP7 expression also correlates with pathophysiology and tumorigenesis. ${ }^{15}$ Here, we explored the potential of serum IGFBP7 levels as a diagnostic and prognostic tool for EJA.

Table 1. Characteristics of the Study Population

\begin{tabular}{|c|c|c|c|c|}
\hline \multirow{2}{*}{ Group } & \multicolumn{3}{|c|}{ EJA $(n=120)$} & \multirow{2}{*}{$\begin{array}{c}\text { Normal (n=88 } \\
\text { No. (\%) }\end{array}$} \\
\hline & No. & 3-yr survival rate (\%) & p-value & \\
\hline \multicolumn{5}{|l|}{ Age, yr } \\
\hline Mean (range) & $60(31-82)$ & & & $56(40-80)$ \\
\hline Sex & & & 0.469 & \\
\hline Male & 99 & 76.4 & & $61(69.3)$ \\
\hline Female & 21 & 49.5 & & $27(30.7)$ \\
\hline Smoke & & & 0.557 & \\
\hline Yes & 79 & 63.6 & & - \\
\hline No & 41 & 69.0 & & - \\
\hline Alcohol & & & 0.038 & \\
\hline Yes & 28 & 46.0 & & - \\
\hline No & 92 & 71.7 & & - \\
\hline Size of tumor, $\mathrm{cm}$ & & & 0.109 & \\
\hline$\geq 5$ & 72 & 60.8 & & - \\
\hline$<5$ & 48 & 72.9 & & - \\
\hline Depth of tumor invasion & & & 0.012 & \\
\hline $\mathrm{T} 1+\mathrm{T} 2+\mathrm{T} 3$ & $36(7+4+25)$ & 79.8 & & - \\
\hline $\mathrm{T} 4$ & 84 & 59.5 & & - \\
\hline Regional lymph nodes & & & $<0.001$ & \\
\hline No & 36 & 73.3 & & - \\
\hline N1 & 31 & 80.6 & & - \\
\hline N2 & 30 & 66.5 & & - \\
\hline N3 & 23 & 33.5 & & - \\
\hline Metastasis & & & $<0.001$ & \\
\hline Mo & 116 & 66.9 & & - \\
\hline M1 & 4 & 25.0 & & - \\
\hline Histological grade & & & 0.019 & \\
\hline G1 (High) & 15 & 84.0 & & - \\
\hline G2 (Middle) & 44 & 68.0 & & - \\
\hline G3 (Low) & 47 & 53.2 & & - \\
\hline Unknown & 14 & - & & - \\
\hline TNM stage & & & 0.055 & \\
\hline $\mathrm{I}+\mathrm{II}$ & $35(9+26)$ & 76.8 & & - \\
\hline III+IV & $85(74+11)$ & 60.7 & & - \\
\hline
\end{tabular}

EJA, esophagogastric junction adenocarcinoma. 
Table 2. Frequency of Circulating IGFBP7

\begin{tabular}{lcccc}
\hline \multicolumn{1}{c}{ Group } & Mean \pm SEM & p-value & No. & Positive (\%, 95\% CI) \\
\hline Normal controls & $1.821 \pm 0.0663$ & - & 88 & $8(9.1,4.7-16.9)$ \\
All EJA & $3.436 \pm 0.1998$ & $<0.001$ & 120 & $76(63.3,54.4-71.4)$ \\
Early-stage EJA & $3.863 \pm 0.5666$ & $<0.001$ & 35 & $19(54.3,36.9-70.8)$ \\
\hline
\end{tabular}

IGFBP7, insulin-like growth factor binding protein 7; SEM, standard error of the mean; CI, exact confidence interval; EJA, esophagogastric junction adenocarcinoma.

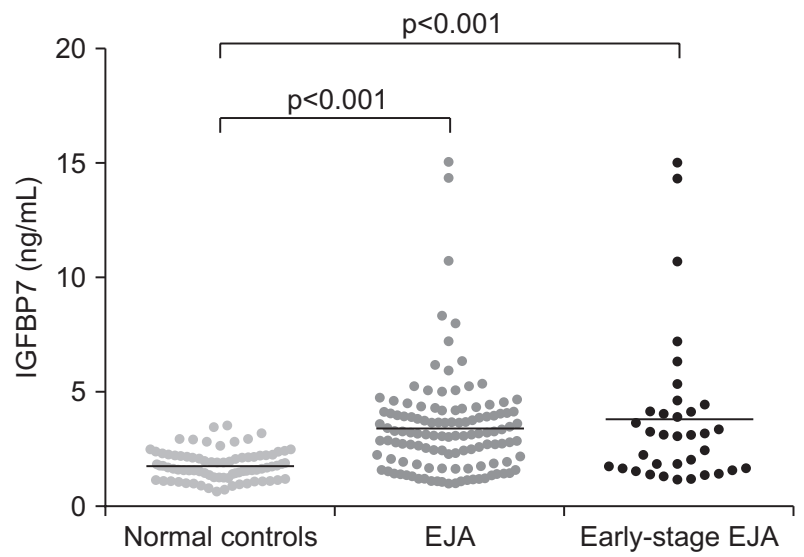

Fig. 1. Scatter plots of serum IGFBP7 values in the normal control group, EJA group and early-stage EJA group.

IGFBP7, insulin-like growth factor binding protein 7; EJA, esophagogastric junction adenocarcinoma. $\mathrm{p}<0.001$ indicates that the difference between the compared groups is statistically significant.

\section{MATERIALS AND METHODS}

\section{Study subjects}

In total, we collected 208 serum samples from the Cancer Hospital of Shantou University Medical College: 88 healthy control samples and 120 EJA samples. All participants were diagnosed to be without acute kidney injury or chronic obstructive pulmonary disease. EJA patient serum samples used in this experiment were collected between July 2013 and November 2017 before surgery, and follow-up was made starting from the day of surgery. The exit date was defined as the day of death, withdrawal or completion of follow-up before December 2018. Both patients and normal controls signed informed consent to participate in this study, which was approved by the Institutional Review Board of the Cancer Hospital of Shantou University Medical College and conformed to the requirements of the Declaration of Helsinki. After venous sampling before surgery, serum was obtained by centrifuging blood at $2500 \mathrm{~g}$ for 10 minutes, then stored at $-80^{\circ} \mathrm{C}$ until analysis.

EJA was diagnosed by computed tomography or gastroscopy, followed by pathological examination after surgery, endoscopic mucosal resection or biopsy. All patients were accepted for surgery. We defined tumor stage according to the 8th edition of the American Joint Committee on Cancer Cancer Staging Manual. ${ }^{3}$ In accordance with our previous study, American Joint Com-

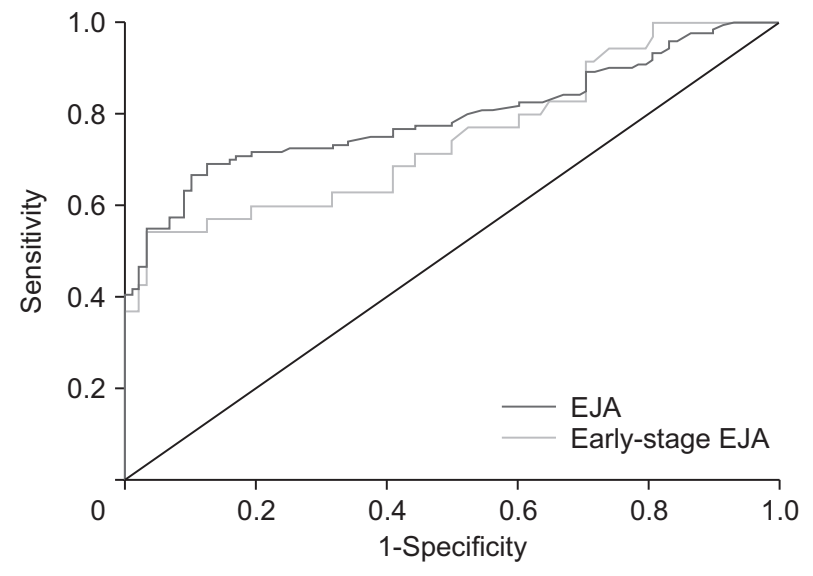

Fig. 2. Receiver operating characteristic curve analysis for the diagnosis of esophagogastric junction adenocarcinoma (EJA) and earlystage EJA.

mittee on Cancer stage I+II was defined as early-stage EJA. ${ }^{16}$

\section{Enzyme-linked immunosorbent assay}

Enzyme-linked immunosorbent assay kits for serum IGFBP-7 were purchased from Cusabio ${ }^{\circledR}$ (Catalog number: CSB-E17249h; Houston, TX, USA). The enzyme-linked immunosorbent assay protocol was carried out according to the user manual. The serum samples were diluted to $1: 3$, while the standard was diluted to a concentration gradient of 10, 5, 2.5, 1.25, 0.625, 0.312, and $0.156 \mathrm{ng} / \mathrm{mL}$, respectively. The $100 \mu \mathrm{L}$ serum sample, standard or sample diluent (acted as negative control) was added to each well and incubated for 2 hours at $37^{\circ} \mathrm{C}$. After removed the liquid, $100 \mu \mathrm{L}$ biotin-antibody (1X) and $100 \mu \mathrm{L}$ horseradish peroxidase-avidin $(1 \mathrm{X})$ were added in chronological order. 3,3',5,5'-tetramethylbenzidine substrate was used for color development and stop solution for the termination of color development. The measurement of optical density value of each well was executed on a plate microplate reader (BioTek ${ }^{\circledR}$ Instruments, Winooski, VT, USA) within 5 minutes at $450 \mathrm{~nm}$ with $570 \mathrm{~nm}$ reference.

\section{Statistical analysis}

We first changed the optical density values to concentration according to the standard curve plotted by SigmaPlot 10.0 Then the Mann-Whitney U-test was used to evaluate the difference of IGFBP7 levels between two groups. Receiver operating 


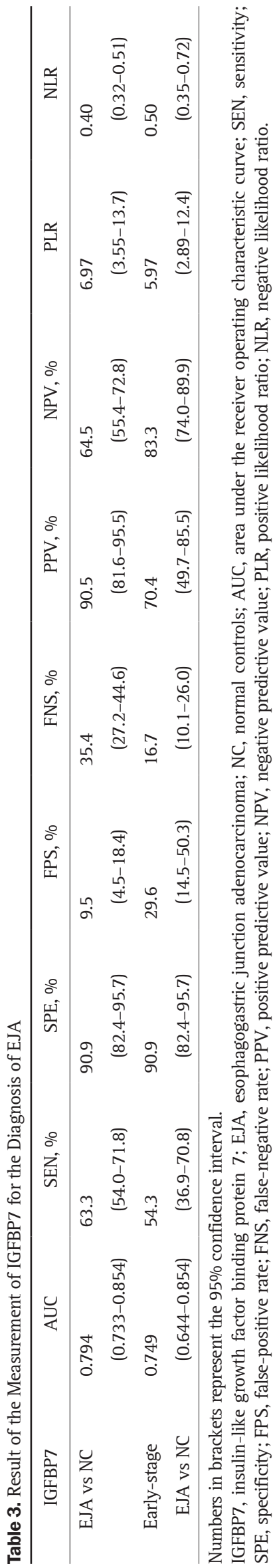

Table 4. Relationship between the Positive Rate of IGFBP7 and the Clinical Data in EJA Patients

\begin{tabular}{|c|c|c|c|}
\hline Variable & Positive & Negative & $\mathrm{p}$-value \\
\hline Age, yr & & & 0.113 \\
\hline$\geq 60$ & 54 & 25 & \\
\hline$<60$ & 22 & 19 & \\
\hline Sex & & & 0.881 \\
\hline Male & 63 & 36 & \\
\hline Female & 13 & 8 & \\
\hline Smoke & & & 0.699 \\
\hline Yes & 51 & 28 & \\
\hline No & 25 & 16 & \\
\hline Alcohol & & & 0.310 \\
\hline Yes & 20 & 8 & \\
\hline No & 56 & 36 & \\
\hline Size of tumor, cm & & & 0.315 \\
\hline$\geq 5$ & 43 & 29 & \\
\hline$<5$ & 33 & 15 & \\
\hline Depth of tumor invasion & & & 0.620 \\
\hline $\mathrm{T} 1+\mathrm{T} 2+\mathrm{T} 3$ & 24 & 12 & \\
\hline $\mathrm{T} 4$ & 52 & 32 & \\
\hline Regional lymph nodes & & & 0.741 \\
\hline No & 22 & 14 & \\
\hline $\mathrm{N} 1+\mathrm{N} 2+\mathrm{N} 3$ & 54 & 30 & \\
\hline Metastasis & & & 1.000 \\
\hline Mo & 73 & 43 & \\
\hline M1 & 3 & 1 & \\
\hline Histological grade & & & 0.562 \\
\hline G1 & 9 & 6 & \\
\hline G2 & 30 & 14 & \\
\hline G3 & 27 & 20 & \\
\hline TNM grade & & & 0.187 \\
\hline Early stage (I-II) & 19 & 16 & \\
\hline Late stage (III-IV) & 57 & 28 & \\
\hline
\end{tabular}

Statistical significance was determined using the Pearson chi-square test. Data were from patients with tumor resection.

IGFBP7, insulin-like growth factor binding protein 7; EJA, esophagogastric junction adenocarcinoma.

characteristic (ROC) analysis was performed to assess the diagnostic boundaries including the area under the ROC curve (AUC) with the 95\% confidence interval (CI), sensitivity and specificity. The cutoff value was calculated by achieving the maximum sensitivity when the specificity was greater than $90 \%$, and by minimizing the distance of the cutoff value to the top-left corner of the ROC curve. We selected a specificity of greater than 90\% in order to produce a test that could be beneficial to early cancer detection. ${ }^{17}$ Correlation between clinical characteristics and the level of IGFBP7 was evaluated by the chi-square test. For optimal cut-point definition in prognostic analysis, we used 

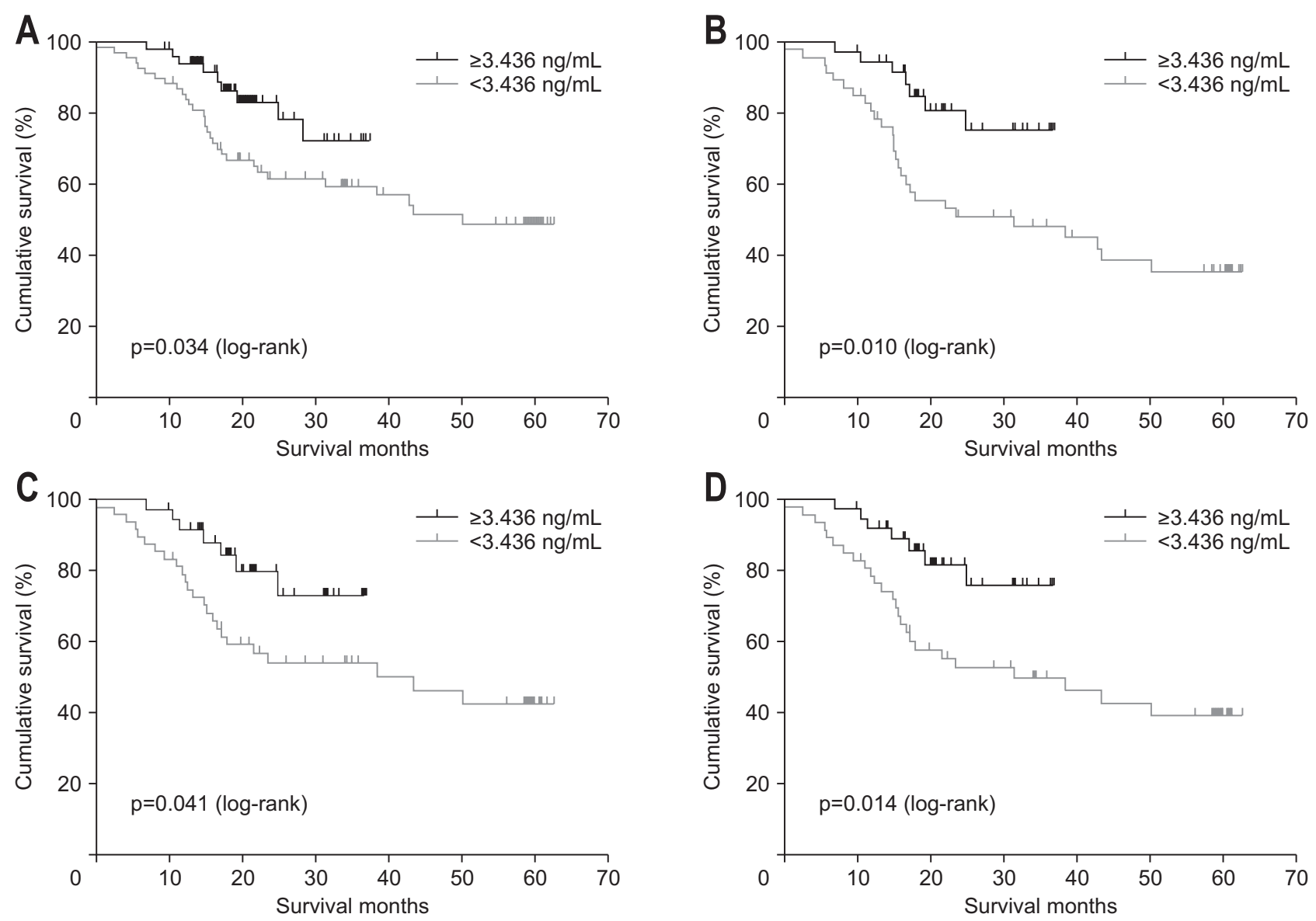

Fig. 3. Kaplan-Meier analysis of overall survival in patients with esophagogastric junction adenocarcinoma (EJA) in relation to IGFBP7 expression. (A) All EJA patients, (B) EJA patients categorized as having T4 disease, (C) EJA patients categorized as having N1+N2+N3 disease, and (D) late-stage EJA patients (III+IV).

IGFBP7, insulin-like growth factor binding protein 7.

the X-tile 3.6.1 software to category high and low expression of IGFBP7. ${ }^{18}$ The Kaplan-Meier survival analysis was used to assess the effect of IGFBP7 on OS. Univariable and multivariable analyses were used to judge the hazard ratio. In all analyses, a $p<0.05$ (two-tailed) was defined as significance. Statistical analyses were carried out with SPSS 18.0 (SPSS Inc., Chicago, IL, USA) and GraphPad Prism 6.0 (GraphPad Software, San Diego, CA, USA).

\section{RESULTS}

\section{Patient characteristics and serum IGFBP7 levels}

A total of 208 patients and normal controls were analyzed (Table 1). The mean concentration \pm standard error of the mean (SEM) of IGFBP7 for EJA patients was $3.436 \pm 0.1998 \mathrm{ng} / \mathrm{mL}$ versus $1.821 \pm 0.0663 \mathrm{ng} / \mathrm{mL}$ and $3.863 \pm 0.5666 \mathrm{ng} / \mathrm{mL}$ in the normal control group and early-stage patient group, respectively (Table 2). Thus, early- and late-stage patients with EJA had a significant increase in level of serum IGFBP7, compared with normal controls $(\mathrm{p}<0.001)$ (Fig. 1). As illustrated in Fig. 1, similar result can be found in early-stage EJA patients.

\section{Diagnostic value of IGFBP7}

We identified a cutoff value of $2.716 \mathrm{ng} / \mathrm{mL}$ for IGFBP7 to diagnose EJA by using the ROC curve to compare the EJA and normal control groups (Fig. 2). We acquired an AUC of 0.794 (95\% CI, 0.733 to 0.854 ) with a sensitivity of 63.3\% (95\% CI, $54.0 \%$ to $71.8 \%$ ) and a specificity of $90.9 \%$ (95\% CI, $82.4 \%$ to $95.7 \%$ ) (Table 3). Also, with the same cutoff value, IGFBP7 could identify early-stage EJA with a slightly lower AUC value of 0.749 (95\% CI, 0.644 to 0.854 ), a sensitivity of 54.3\% (95\% CI, $36.9 \%$ to $70.8 \%$ ) and a specificity of $90.9 \%$ (95\% CI, $82.4 \%$ to $95.7 \%)$.

\section{Correlation with clinical data}

With the cutoff value of $2.716 \mathrm{ng} / \mathrm{mL}$, we defined the positivity of the serum IGFBP7 levels for EJA patients to be over 2.716 $\mathrm{ng} / \mathrm{mL}$. Table 4 shows the relationship of serum IGFBP7 levels with clinicopathological features in EJA. IGFBP7 showed no association with any clinical data, including patient age, gender, smoking, drinking, size, depth of invasion, histological grade, lymph node status, metastasis, and early-stage versus advanced- 
Table 5. Univariate and Multivariate Analyses of Factors Associated with Overall Survival in Patients with EJA

\begin{tabular}{|c|c|c|c|c|}
\hline \multirow{2}{*}{ Variable } & \multicolumn{2}{|c|}{ Univariate analysis } & \multicolumn{2}{|c|}{ Multivariate analysis } \\
\hline & HR (95\% CI) & p-value & $\operatorname{HR}(95 \% \mathrm{CI})$ & p-value \\
\hline Age ( $\geq 60$ yr vs <60 yr) & 0.995 (0.955-1.037) & 0.819 & & \\
\hline Sex (female vs male) & $0.750(0.343-1.640)$ & 0.471 & & \\
\hline Smoke (yes vs no) & $1.226(0.620-2.426)$ & 0.558 & & \\
\hline Alcohol (yes vs no) & $2.007(1.025-3.931)$ & 0.042 & & \\
\hline Tumor size ( $\geq 5 \mathrm{~cm}$ vs $<5 \mathrm{~cm}$ ) & $1.759(0.874-3.538)$ & 0.113 & & \\
\hline T (T4 vs T1+T2+T3) & $3.114(1.217-7.966)$ & 0.018 & $3.362(1.310-8.625)$ & 0.012 \\
\hline $\mathrm{N}(\mathrm{N} 1+\mathrm{N} 2+\mathrm{N} 3$ vs N0) & $1.996(0.917-4.346)$ & 0.082 & & \\
\hline M (M1 vs M0) & $7.445(2.225-24.904)$ & 0.001 & $11.303(3.101-41.202)$ & $<0.001$ \\
\hline G (G2+G3 vs G1) & $3.734(0.897-15.553)$ & 0.070 & & \\
\hline pTNM-stage (III+IV vs I+II) & $2.183(0.963-4.949)$ & 0.062 & & \\
\hline IGFBP7 ( $\geq 3.436$ vs <3.436) & $0.433(0.195-0.962)$ & 0.040 & $0.351(0.157-0.786)$ & 0.011 \\
\hline
\end{tabular}

Multivariate analysis, Cox proportional hazards regression model. Variables were adopted for their prognostic significance according to the univariate analysis.

EJA, esophagogastric junction adenocarcinoma; HR, hazard ratio; CI, confidence interval; IGFBP7, insulin-like growth factor binding protein 7.

stage groups (all $\mathrm{p}>0.05$ ).

\section{Correlation between IGFBP7 expression and OS}

According to X-tile software, we set $3.436 \mathrm{ng} / \mathrm{mL}$ as the cutoff value to classify high and low expression of IGFBP7. The difference in 3-year OS for EJA patients with high IGFBP7 levels had 72.4\% 3-year OS versus 59.7\% for patients with low expression (Fig. 3A), and the difference was statistically significant $(p=0.034)$. When we stratified according to staging, the same results were found in subgroups categorized with $\mathrm{T} 4(\mathrm{p}=0.010)$, $\mathrm{N} 1+\mathrm{N} 2+\mathrm{N} 3$ ( $\mathrm{p}=0.041)$, and III+IV ( $\mathrm{p}=0.014)$ (Fig. 3B-D). Upon univariable analysis, IGFBP7 was a significant prognostic factor for 3-year OS of EJA patients ( $\mathrm{p}=0.040$ ) (Table 5). Upon multivariable analysis, IGFBP7 was an independent significant prognostic marker for 3-year OS (hazard ratio, 0.351; 95\% CI, 0.157 to $0.786 ; p=0.011)$. Other significant variables included further metastasis $(p<0.001)$ and depth of tumor invasion $(p=0.012)$.

\section{DISCUSSION}

In our study, IGFBP7 was significantly higher in both earlyand late-stage EJA compared to normal controls ( $p<0.001)$. For diagnosis, we achieved an AUC of 0.794 (95\% CI, 0.733 to 0.854) and cutoff value of $2.716 \mathrm{ng} / \mathrm{mL}$ with sensitivity of $63.3 \%$ (95\% CI, $54.0 \%$ to $71.8 \%$ ) and specificity of $90.9 \%$ (95\% CI, $82.4 \%$ to 95.7\%) in EJA. Furthermore, we found that the level of serum IGFBP7 is not associated with any clinical parameters. However, if diagnosed with EJA, lower IGFBP7 expression may lead to the worse survival.

IGF family members regulate cell proliferation, differentiation and apoptosis through the MAPK and PI3K/Akt signaling pathways. ${ }^{19}$ They have also been demonstrated to correlate with many cancers. ${ }^{20-22}$ IGFBP7, also named IGFBP-rP1, is one of the members in IGF family. Although it shares 30\% structural homology with IGFBP1 to IGFBP6 at its N-terminal domain, as it binds to IGF with low affinity ${ }^{10,23}$ and its individual characteristics are different from IGFBP1 to IGFBP6. Methylation of IGFBP7 may reduce the expression of IGFBP7 in gastric cancer and prostate cancer and improve the tumor progression, ${ }^{13,24}$ and administration of IGFBP7 may be therapeutic for reducing breast cancer growth. ${ }^{25}$ However, prior studies investigated expression in mostly cells and tissues. Serum expression of IGFBP7 has only been studied in a few diseases, such as chronic obstructive pulmonary disease ${ }^{12}$ and metabolic syndrome. ${ }^{26}$ Therefore, we evaluated the potential diagnostic and prognostic value of circulating IGFBP7 in EJA.

Early detection is one of the best methods to reduce cancer mortality and cancer burden. ${ }^{27}$ In clinical practice, endoscopy contributes to the early diagnosis of EJA. ${ }^{28}$ However, it is invasive and may produce adverse effects, such as infection, perforation, and bleeding. ${ }^{29}$ A recent study on serum autoantibody panels to detect EJA aroused our interest to identify noninvasive techniques to detect IGFBP7 in EJA patient serum. ${ }^{16}$ When accounting for the early detection of IGFBP7 in EJA, through ROC curve analysis, we found an AUC of 0.749 (95\% CI, 0.644 to 0.854 ), which led to a sensitivity of $54.3 \%$ (95\% CI, 36.9\% to $70.8 \%$ ) and specificity of $90.9 \%$ (95\% CI, 82.4\% to $95.7 \%$ ). Although there was no statistical correlation between late-stage

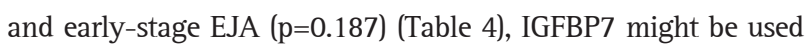
as a potential biomarker for the early detection of EJA. Actually, there have been several studies on serum IGFBP7 in other cancers. Overexpression of serum IGFBP7 has been observed in high-grade soft tissue sarcoma, ${ }^{30}$ and high levels of serum IGFBP7 have been associated with positive nodal status in 
non-small cell lung cancer. ${ }^{31}$ However, both of them have not researched on the early-stage cancer. Additionally, our recent study has showed serum IGFBP7 might serve as a diagnostic biomarker for esophageal cancer, ${ }^{32}$ and it also made sense in early-stage esophageal cancer. Herein, although IGFBP7 is not a unique biomarker for EJA, it still may be a valuable candidate for EJA, in particular for the early detection of EJA.

Although Smith et al. ${ }^{33}$ suggested that the expression of IGFBP7 is related to poor prognosis in esophageal squamous cell carcinoma, as described in many cancers, such as thyroid, ${ }^{34}$ lung, ${ }^{35}$ liver, ${ }^{36}$ and ovarian, ${ }^{37}$ a high level of IGFBP7 gene expression could be a potential protective factor to suppress the growth of tumor cells. However, all of these studies were based on IGFBP7 expression at the level of tissues or cells. Therefore, we extended these studies to serum expression. As our study shows, low serum IGFBP7 concentration is associated with poor outcome $(p=0.034)$, and multivariate analysis suggests that the level of serum IGFBP7 protein expression is an independent prognostic factor for EJA ( $\mathrm{p}=0.011)$, suggesting that serum IGFBP7 might be also a potential prognostic marker for EJA.

In summary, our study offers useful information regarding the diagnostic value of serum IGFBP7 in EJA and suggests that IGFBP7 might be a potential biomarker for the detection and diagnosis of EJA. Additionally, low expression of IGFBP7, acting as an independent factor, might predict the poor prognosis of EJA. However, this was a single-institution study with a small sample size, which may lead to bias. A study with large sample size in multiple institutions should be performed to further verify the diagnostic value of IGFBP7 in EJA, especially early-stage EJA.

\section{CONFLICTS OF INTEREST}

No potential conflict of interest relevant to this article was reported.

\section{ACKNOWLEDGEMENTS}

This work was supported by grants from the National Natural Science Foundation of China (81972801 and 31600632); the Natural Science Foundation of Guangdong Province (2018A030307079); the Innovative and Strong School Project of Guangdong (2018KTSCX068) and the Grant for Key Disciplinary Project of Clinical Medicine under the Guangdong Highlevel University Development Program.

\section{AUTHOR CONTRIBUTIONS}

Experiments: C.T.L., Y.W.X., X.Y.H. Data analysis: C.T.L., L.Y.C., S.H.Y. Technical or material support: C.Q.H. Serum and clinical data collection: H.G., Y.H.L. Writing - original draft and review and editing: C.T.L., Y.W.X. Study design and obtained funding: Y.W.X., E.M.L., Y.H.P. All authors read and approved the final manuscript.

\section{ORCID}

Can-Tong Liu

Yi-Wei Xu

Hong Guo

Chao-Qun Hong

Xin-Yi Huang

Yu-Hao Luo

Shi-Han Yang

Ling-Yu Chu

En-Min Li

Yu-Hui Peng https://orcid.org/0000-0001-6479-8793 https://orcid.org/0000-0002-8670-592X https://orcid.org/0000-0001-7735-2061 https://orcid.org/0000-0002-7090-2355 https://orcid.org/0000-0002-8107-1446 https://orcid.org/0000-0002-7186-5242 https://orcid.org/0000-0002-9007-0234 https://orcid.org/0000-0002-4682-0931 https://orcid.org/0000-0001-6375-3614 https://orcid.org/0000-0002-1866-4679

\section{REFERENCES}

1. Oda I, Abe S, Kusano C, et al. Correlation between endoscopic macroscopic type and invasion depth for early esophagogastric junction adenocarcinomas. Gastric Cancer 2011;14:22-27.

2. Siewert JR, Stein HJ. Classification of adenocarcinoma of the oesophagogastric junction. Br J Surg 1998;85:1457-1459.

3. Rice TW, Gress DM, Patil DT, Hofstetter WL, Kelsen DP, Blackstone EH. Cancer of the esophagus and esophagogastric junctionMajor changes in the American Joint Committee on Cancer eighth edition cancer staging manual. CA Cancer J Clin 2017;67:304317.

4. Hartgrink HH, Jansen EP, van Grieken NC, van de Velde CJ. Gastric cancer. Lancet 2009;374:477-490.

5. Thrift AP. The epidemic of oesophageal carcinoma: where are we now? Cancer Epidemiol 2016;41:88-95.

6. Kim HS, Nagalla SR, Oh Y, Wilson E, Roberts CT Jr, Rosenfeld RG. Identification of a family of low-affinity insulin-like growth factor binding proteins (IGFBPs): characterization of connective tissue growth factor as a member of the IGFBP superfamily. Proc Natl Acad Sci U S A 1997;94:12981-12986.

7. Khandwala HM, McCutcheon IE, Flyvbjerg A, Friend KE. The effects of insulin-like growth factors on tumorigenesis and neoplastic growth. Endocr Rev 2000;21:215-244.

8. Pollak M. The insulin and insulin-like growth factor receptor family in neoplasia: an update. Nat Rev Cancer 2012;12:159-169.

9. Fürstenberger G, Senn HJ. Insulin-like growth factors and cancer. Lancet Oncol 2002;3:298-302.

10. Oh Y, Nagalla SR, Yamanaka Y, Kim HS, Wilson E, Rosenfeld RG. Synthesis and characterization of insulin-like growth factor-binding protein (IGFBP)-7: recombinant human mac25 protein specifically binds IGF-I and -II. J Biol Chem 1996;271:30322-30325.

11. Liu KD, Vijayan A, Rosner MH, Shi J, Chawla LS, Kellum JA. Clinical adjudication in acute kidney injury studies: findings from the pivotal TIMP-2*IGFBP7 biomarker study. Nephrol Dial Transplant 2016;31:1641-1646. 
12. Ruan W, Wu M, Shi L, et al. Serum levels of IGFBP7 are elevated during acute exacerbation in COPD patients. Int J Chron Obstruct Pulmon Dis 2017;12:1775-1780.

13. Kim J, Kim WH, Byeon SJ, Lee BL, Kim MA. Epigenetic downregulation and growth inhibition of IGFBP7 in gastric cancer. Asian Pac J Cancer Prev 2018;19:667-675.

14. Rao C, Lin SL, Ruan WJ, Wen H, Wu DJ, Deng H. High expression of IGFBP7 in fibroblasts induced by colorectal cancer cells is coregulated by TGF-beta and Wnt signaling in a Smad2/3-Dvl2/3dependent manner. PLoS One 2014;9:e85340.

15. Kashyap MK. Role of insulin-like growth factor-binding proteins in the pathophysiology and tumorigenesis of gastroesophageal cancers. Tumour Biol 2015;36:8247-8257.

16. Xu YW, Chen H, Guo HP, et al. Combined detection of serum autoantibodies as diagnostic biomarkers in esophagogastric junction adenocarcinoma. Gastric Cancer 2019;22:546-557.

17. Boyle P, Chapman CJ, Holdenrieder S, et al. Clinical validation of an autoantibody test for lung cancer. Ann Oncol 2011;22:383389.

18. Camp RL, Dolled-Filhart M, Rimm DL. X-tile: a new bio-informatics tool for biomarker assessment and outcome-based cut-point optimization. Clin Cancer Res 2004;10:7252-7259.

19. Kasprzak A, Kwasniewski W, Adamek A, Gozdzicka-Jozefiak A. Insulin-like growth factor (IGF) axis in cancerogenesis. Mutat Res Rev Mutat Res 2017;772:78-104.

20. Cao H, Wang G, Meng L, et al. Association between circulating levels of IGF-1 and IGFBP-3 and lung cancer risk: a meta-analysis. PLoS One 2012;7:e49884.

21. Ma J, Pollak MN, Giovannucci E, et al. Prospective study of colorectal cancer risk in men and plasma levels of insulin-like growth factor (IGF)-I and IGF-binding protein-3. J Natl Cancer Inst 1999;91:620-625.

22. Yi HK, Hwang PH, Yang DH, Kang CW, Lee DY. Expression of the insulin-like growth factors (IGFs) and the IGF-binding proteins (IGFBPs) in human gastric cancer cells. Eur J Cancer 2001;37:2257-2263.

23. Burger AM, Leyland-Jones B, Banerjee K, Spyropoulos DD, Seth AK. Essential roles of IGFBP-3 and IGFBP-rP1 in breast cancer Eur J Cancer 2005;41:1515-1527.

24. Sullivan L, Murphy TM, Barrett C, et al. IGFBP7 promoter methylation and gene expression analysis in prostate cancer. J Urol
2012;188:1354-1360.

25. Benatar T, Yang W, Amemiya Y, et al. IGFBP7 reduces breast tumor growth by induction of senescence and apoptosis pathways. Breast Cancer Res Treat 2012;133:563-573.

26. Liu Y, Wu M, Ling J, et al. Serum IGFBP7 levels associate with insulin resistance and the risk of metabolic syndrome in a Chinese population. Sci Rep 2015;5:10227.

27. Etzioni R, Urban N, Ramsey S, et al. The case for early detection. Nat Rev Cancer 2003;3:243-252.

28. Ajani JA, Barthel JS, Bentrem DJ, et al. Esophageal and esophagogastric junction cancers. J Natl Compr Canc Netw 2011;9:830887.

29. ASGE Standards of Practice Committee, Ben-Menachem T, Decker GA, et al. Adverse events of upper GI endoscopy. Gastrointest Endosc 2012;76:707-718.

30. Benassi MS, Pazzaglia L, Novello C, et al. Tissue and serum IGFBP7 protein as biomarker in high-grade soft tissue sarcoma. Am J Cancer Res 2015;5:3446-3454.

31. Shersher DD, Vercillo MS, Fhied C, et al. Biomarkers of the insulin-like growth factor pathway predict progression and outcome in lung cancer. Ann Thorac Surg 2011;92:1805-1811.

32. Huang X, Hong C, Peng $Y$, et al. The diagnostic value of serum IGFBP7 in patients with esophageal squamous cell carcinoma. J Cancer 2019;10:2687-2693.

33. Smith E, Ruszkiewicz AR, Jamieson GG, Drew PA. IGFBP7 is associated with poor prognosis in oesophageal adenocarcinoma and is regulated by promoter DNA methylation. Br J Cancer 2014;110:775-782.

34. Vizioli MG, Sensi M, Miranda C, et al. IGFBP7: an oncosuppressor gene in thyroid carcinogenesis. Oncogene 2010;29:3835-3844.

35. Chen Y, Pacyna-Gengelbach M, Ye F, et al. Insulin-like growth factor binding protein-related protein 1 (IGFBP-rP1) has potential tumour-suppressive activity in human lung cancer. J Pathol 2007;211:431-438.

36. Chen D, Yoo BK, Santhekadur PK, et al. Insulin-like growth factorbinding protein-7 functions as a potential tumor suppressor in hepatocellular carcinoma. Clin Cancer Res 2011;17:6693-6701.

37. Gambaro K, Quinn MC, Cáceres-Gorriti KY, et al. Low levels of IGFBP7 expression in high-grade serous ovarian carcinoma is associated with patient outcome. BMC Cancer 2015;15:135. 